\title{
ANTIOXIDANT POTENTIAL PROFILE OF PAJANELIA LONGIFOLIA (WILLD.) K. SCHUMAN; POTENTIAL NEW SOURCES OF NATURAL ANTIOXIDANT
}

\author{
PRIYANKA SAHA, ANUPAM DAS TALUKDAR*, MANABENDRA DUTTA CHOUDHURY
}

Department of Life Science \& Bioinformatics, Ethnobotany \& Medicinal Plant Research Laboratory, Assam University, Silchar - 788 011, Assam, India. Email: anupam@bioinfoaus.ac.in

Received: 15 February 2017, Revised and Accepted: 15 March 2017

\section{ABSTRACT}

Objectives: The aim of the present work is to screen the antioxidant potentiality of the bark extracts of Pajanelia longifolia (Willd.) K. Schuman, ethnomedicinally prescribed plant as hepatoprotective.

Methods: Bark extract was prepared using Soxhlet apparatus. Total phenol, flavonoid, total alkaloid were analyzed using Folin-Ciocalteu assay, aluminum chloride calorimetric assay, atropine standard, respectively. Antioxidant capacity and free radical scavenging potentialities were done by various in vitro methods, viz.; 1,1-diphenyl-2-picrylhydrazyl (DPPH), hydrogen peroxide scavenging activity, reducing power assay, metal chelating activity, ferric reducing antioxidant power (FRAP) assay, and thiobarbituric acid (TBA) method.

Result: Total phenol, flavonoid, and alkaloid were found to be highest in acetone extract of $P$. longifolia (Willd.) K. Schuman. Acetone extracts of the bark of $P$. longifolia (Willd.) K. Schuman showed very low inhibitory concentration 50 (IC ${ }_{50}$ ) and effective concentration 50 (EC 50 ) values for DPPH assay and reducing power assay compared to other extracts. In hydrogen peroxide scavenging activity assay, the lowest $\mathrm{IC}_{50}$ value was recorded in acetone extract with $181.78 \pm 0.09 \mu \mathrm{g} / \mathrm{ml}$ in $P$. longifolia. The FRAP assay for P. longifolia acetone extract showed the highest activity at $967 \pm 0.69 \mu \mathrm{g} / \mathrm{ml}$ of ascorbic acid equivalent. The ferric reducing capacity and TBA values of the plant extracts confirmed the presence antioxidant principles in the bark of the said plant.

Conclusion: These underused plant may be used for mitigating the detrimental effect of oxidative stress and reactive oxygen species-mediated disease and thus justifies its use in folklore medicines.

Keywords: Antioxidant, Free radical, Oxidative stress, Phenols, Flavonoids, Alkaloids, Pajanelia longifolia (Willd.) K. Schuman.

(C) 2017 The Authors. Published by Innovare Academic Sciences Pvt Ltd. This is an open access article under the CC BY license (http://creativecommons. org/licenses/by/4. 0/) DOI: http://dx.doi.org/10.22159/ajpcr.2017.v10i6.17750

\section{INTRODUCTION}

Reactive oxygen intermediates have been the unwelcome companion of aerobic metabolism. Natural antioxidants can attenuate the oxidative damage of tissues either by enhancing natural defenses of cell or directly by scavenging the free radical species. Phytochemicals, belonging to several chemical groups are drawing attention of scientist to find more effective antioxidants from plant species.

Pajanelia longifolia (Willd.) K. Schuman, family Bignoniaceae, is commonly distributed in the Western Ghats and Eastern Bengal in India and other tropical countries such as Bangladesh, Myanmmar, and Burma. One of the earliest treatises on Indian medicine, the Charaka Samhita (1000 BC), records the use of this plant in the treatment of arthritis, stomach disorder, urinary disorders, etc. This plant also finds its importance in local folklore practitioners in Karnataka for obesity [1]. Ethnobotanical investigation of tribal of Cachar district, Assam, India, revealed the use of bark decoction of this plant in liver ulcer and jaundice since for many years and their effectiveness is widely acclaimed among these tribal communities [2,3]. Within the tribal communities of Southern Assam, the crude extract of leaves of $P$. longifolia is use to apply on skin to cure infection. The bark of the plant is conventionally claimed to have hepatoprotective property $[2,3]$. Within the tribal communities of Southern Assam, the crude extract of leaves of $P$. longifolia is use to apply on skin to cure infection [2]. The presence of secondary metabolites like phenol in the bark have been documented in the work of Zainab et al. 2013 where they established for the first time its levels of antioxidant and antimicrobial activity in its bark. Antibacterial activity of was reported in its leaves where the leaf extracts containing polar components showed potential antibacterial activity $[3,4]$. The preliminary hepatoprotective activity of the stem bark of this plant has been reported by Datta et al. 2012 [5]. Although many phytochemicals have been reported from other plants of this family, $P$. longifolia is little studied except for a potent bioactive compound, Pajaneelin [6] discovered long back in $19^{\text {th }}$ century. Motivated by the ethnomedicinal history of these plants and given in the situation of the present status of research, this study focuses on evaluating detailed comparative antioxidant property of different bark extracts of $P$. longifolia to consider it as a natural antioxidant.

\section{METHODS}

\section{Collection of plant material}

The bark of plant was collected from Southern Assam of Cachar district (Northeast India). It was identified and submitted in Assam University Herbaria with voucher specimen no. 2577. After proper washing, the dried parts of the plant were pulverized separately into fine powder and were used for preparation of extracts.

\section{Chemicals and equipment}

All chemicals used were of analytical reagent grade. Ascorbic acid, atropine, gallic acid, butylated hydroxyl anisole, aluminum chloride, Folin-Ciocalteu reagent, ammonium thiocyanate, disodium phosphate, monosodium dihydrogen phosphate, trichloroacetic acid, hydrogen peroxide, iron (III) chloride and iron (II) chloride were purchased from Merck chemicals (Mumbai); and 2,2-diphenyl-2-picrylhydrazyl (DPPH), ascorbic acid, glacial acetic acid and tripyridyl-triazine (TPTZ) were purchased from HiMedia Laboratories (Mumbai). Absorbances were taken using ultraviolet visible spectrophotometer (Labomed, Inc., USA). Other chemicals and solvents were purchased from Merck chemicals, Mumbai, India. 
Preparation of extracts

About $50 \mathrm{~g}$ of powdered bark samples of both the plants were used for extraction by Soxhlet system using different solvents, viz.; hexane, ethyl acetate, acetone, and methanol. The filtrates were concentrated under reduced pressure by rotatory evaporator. The resulting residue was then filtered and stored at $4^{\circ} \mathrm{C}$ for further antioxidant assays.

\section{Quantitative phytochemical analysis}

Quantitative phytochemical assays were performed with focus on testing different chemical groups present in different solvent extracts of $P$. longifolia.

\section{Determination of phenols}

Total phenolic constituent of the extracts was determined with standard protocol [7]. $1 \mathrm{ml}$ of $2000 \mu \mathrm{g}$ extract solution was added to a volumetric flask. $45 \mathrm{ml}$ distilled water and $1 \mathrm{ml}$ Folin-Ciocalteu reagents were then added and were shaken vigorously. After 3 minutes, $3 \mathrm{ml}$ of $\mathrm{Na}_{2} \mathrm{CO}_{3}(2 \%)$ solution was added and the mixture was allowed to stand for 2 hrs by intermittent shaking. Absorbance was measured at $760 \mathrm{~nm}$. Results were expressed in $\mu \mathrm{g}$ gallic acid equivalent (GAE)/mg of plant extracts.

\section{Determination of flavonoids}

Total flavonoid content (TFC) was determined using the Dowd method [8]. $1 \mathrm{ml}$ of $2 \%$ aluminum trichloride $\left(\mathrm{AlCl}_{3}\right)$ was mixed in methanol with the same volume of the various extracts $(2000 \mu \mathrm{g})$. The absorbance was read at $415 \mathrm{~nm}$ after 10 minutes against blank consisting of $1 \mathrm{ml}$ extract solution with $1 \mathrm{ml}$ methanol without $\mathrm{AlCl}_{3}$, and the flavonoid content was expressed as $\mu \mathrm{g}$ quercetin equivalent $/ \mathrm{mg}$ of plant extract.

\section{Determination of alkaloids}

A part of dried solvent extract was dissolved in $2 \mathrm{~N} \mathrm{HCl}$ and then filtered. $1 \mathrm{ml}$ of filtrate was washed with $10 \mathrm{ml}$ chloroform in a separatory funnel. The $\mathrm{pH}$ of this solution was then adjusted to neutral with $0.1 \mathrm{~N} \mathrm{NaOH} .5 \mathrm{ml}$ of bromocresol green solution and $5 \mathrm{ml}$ of phosphate buffer were added. The mixture was extracted with chloroform by shaking; the extracted mixture was then diluted with chloroform [9]. The absorbance was measured at spectrum of $470 \mathrm{~nm}$, and the result was expressed as $\mu \mathrm{g}$ atropine equivalent/mg of plant extract.

\section{In vitro antioxidant assays}

\section{Determination of DPPH free-radical scavenging activity}

The free radical scavenging activity of the plant extracts was measured using DPPH by the method of Kumarasamy et al. [10] $80 \mu \mathrm{g} / \mathrm{ml}$. DPPH was prepared with methanol. Serial dilutions were carried out with the $1 \mathrm{mg} / \mathrm{ml}$ stock solutions of the extracts. $2 \mathrm{ml}$ of each solution were then mixed with $2 \mathrm{ml}$ of DPPH and allowed to stand for 30 minutes; the absorbance was then read at $517 \mathrm{~nm}$. Ascorbic acid was used as standard. Inhibitory concentration $\left(\mathrm{IC}_{50}\right.$ ) value for each part was also calculated using a concentration-response curve. Inhibition of DPPH free radical in percentage was calculated by formula:

DPPH radical scavenging activity $(\%)=($ A control $-A$ test $) / A$ control $\times 100$

\section{Reducing power assay}

The reducing power assay was conducted according to the method of Oyaizu [11]. To $2.5 \mathrm{ml}(1 \mathrm{mg} / \mathrm{ml})$ of a plant extract, $2.5 \mathrm{ml}$ of $0.2 \mathrm{~mol} / \mathrm{l}$ sodium phosphate buffer and $2.5 \mathrm{ml}$ of $1 \%$ potassium ferricyanide were mixed. After incubating the mixture at $50^{\circ} \mathrm{C}$ for 20 minutes, $2.5 \mathrm{ml}$ trichloroacetic acid solution was added and the mixture was centrifuged at $650 \mathrm{rpm}$ and $25^{\circ} \mathrm{C}$ for 10 minutes. The supernatant ( $5 \mathrm{ml}$ ) was mixed with $5 \mathrm{ml}$ distilled water and $1 \mathrm{ml}$ ferric chloride solution. The absorbance was measured at $700 \mathrm{~nm}$. Ascorbic acid was used as standard.

\section{Hydrogen peroxide scavenging assay}

Hydrogen peroxide scavenging potential of the plant extract was determined using the method described by Jayaprakasha et al. [12]. A solution of hydrogen peroxide $(20 \mathrm{mM})$ was prepared in phosphate buffer saline (PBS, pH 7.4). Different concentrations of the extract $(20-100 \mu \mathrm{g} / \mathrm{ml})$ in ethanol $(1 \mathrm{ml})$ were added to $2 \mathrm{ml}$ of hydrogen peroxide solution in PBS. After 10 minutes, the absorbance was measured at $230 \mathrm{~nm}$ against blank solution that contained hydrogen peroxide solution without the extract. The percentage of $\mathrm{H}_{2} \mathrm{O}_{2}$ scavenging of the plant extract was calculated as follows:

$\%$ scavenged $\left(\mathrm{H}_{2} \mathrm{O}_{2}\right)=([$ Abs control-Abs sample $] /$ Abs control $) \times 100$

\section{Ferric reducing antioxidant power (FRAP) assay}

The antioxidant activity analysis using FRAP was performed according to the method reported by Benzie and Strain [13]. The stock solutions included $300 \mathrm{mM}$ acetate buffer $\mathrm{pH}$ 3.6, $10 \mathrm{mM} \mathrm{2,} \mathrm{4,} \mathrm{6-TPTZ} \mathrm{solution}$ in $40 \mathrm{mM} \mathrm{HCl}$, and $20 \mathrm{Mm} \mathrm{FeCl}_{3} \cdot 6 \mathrm{H}_{2} \mathrm{O}$ solutions. The fresh working solution was prepared by mixing $25 \mathrm{ml}$ acetate buffer, $2.5 \mathrm{ml} \mathrm{TPTZ}$, and $2.5 \mathrm{ml} \mathrm{FeCl} \cdot 6 \mathrm{H}_{2} \mathrm{O}$. The temperature of the solution was raised to $37^{\circ} \mathrm{C}$ before use. Various solvent extract $(200 \mu \mathrm{l})$ was allowed to react with $2800 \mu \mathrm{l}$ of the FRAP solution for 30 minutes in the dark condition. Readings of the colored product (ferrous TPTZ complex) were taken at $593 \mathrm{~nm}$. The FRAP values of samples were expressed as $\mu \mathrm{g} / \mathrm{ml}$ of ascorbic acid equivalent (AAE).

\section{Measurement of ferrous ion chelating ability}

The chelating ion by various plant extracts from the bark of $P$. longifolia was measured by the method of Yan et al. [14]. Various concentrations of the solvent extract such as 50,100,150,200,250, and $300 \mu \mathrm{g} / \mathrm{ml}$ of $P$. longifolia were added with $1 \mathrm{ml}$ of $2 \mathrm{mM} \mathrm{FeCl}_{2}$ separately. The reaction was initiated by the addition of $5 \mathrm{mM}$ ferrozine $(1 \mathrm{ml})$. Absorbance was measured at $562 \mathrm{~nm}$ after 10 minutes. Ascorbic acid was used as standard.

$$
\text { Chelating activity }(\%)=\frac{\text { Control OD }- \text { Sample OD }}{\text { Control OD }} \times 100
$$

\section{Thiobarbituric acid (TBA) method}

This assay was performed according to the method reported by Kikuzaki and Nakatani [15]. $2 \mathrm{ml}$ of $20 \%$ trichloroacetic acid and $2 \mathrm{ml}$ of $0.67 \%$ of TBA were added to $1 \mathrm{ml}$ of sample solution. The mixture was placed in a boiling water bath for 10 minutes and then centrifuged at $3000 \mathrm{rpm}$ for 20 minutes. The absorbance of supernatant was measured at $552 \mathrm{~nm}$. The inhibition rate was calculated using the following equation:

$[(\mathrm{Ac}-\mathrm{As}) / \mathrm{Ac}] \times 100$

Where, Ac is the absorbance of the control and As is the absorbance of the sample.

\section{RESULTS}

Total phenolic, flavonoids, alkaloid content of the extract

In this study, acetone extract of $P$. longifolia bark possessed highest phenolic contents (56.42 $\mu \mathrm{g} \mathrm{GAE} / \mathrm{mg}$ of extract) and flavonoid content (102.72 $\mu$ g quercetin/mg of extract) Table 1. Total phenolic content was calculated using the standard curve of gallic acid (standard equation curve equation: $Y=0.0033 x+0.0378$; $R^{2}=0.9761$ ), (TFC) was calculated using the standard curve of quercetin (standard equation curve equation: $\mathrm{Y}=0.03576 \mathrm{x}+0.211 ; \mathrm{R}^{2}=0.9922$ ) and total alkaloid content was calculated using the standard curve of atropine (standard equation curve equation: $Y=0.0003 x+0.0052 ; R^{2}=0.9862$ ) (Fig. 1).

\section{DPPH radical scavenging assay}

The results of DPPH radical scavenging activity of the P. longifolia and the standard ascorbic acid $\left(\mathrm{IC}_{50}=12.25 \pm 0.01 \mu \mathrm{g} / \mathrm{ml}\right.$ ) are presented in Fig. 2. The percentage inhibitory activity of free radicals by $50 \%$ has been used widely as a parameter to measure antioxidant activity. In this study, both the plant extract and standard significantly scavenged the DPPH radical with increasing concentrations. Fig. 2 showed the dose response curve of DPPH radical scavenging activity. 
Table 1: TPC, TFC and TAC estimation of various extracts of $P$. longifolia

\begin{tabular}{llll}
\hline Extract & TPC $(\boldsymbol{\mu g}$ GAEs $/ \mathbf{m g}$ of extract) & TFC $(\boldsymbol{\mu g}$ quercetin $/ \mathbf{m g}$ of extract) & TAC $(\boldsymbol{\mu g}$ atropine $/ \mathbf{m g}$ of extract) \\
\hline Hexane & $09.87 \pm 0.07$ & $31.54 \pm 0.03$ & $29.00 \pm 0.5$ \\
Ethyl acetate & $17.90 \pm 0.03$ & $31.15 \pm 0.4$ & $37.42 \pm 1.9$ \\
Acetone & $56.42 \pm 0.00$ & $102.72 \pm 0.01$ & $105.66 \pm 0.8$ \\
Methanol & $40.09 \pm 0.01$ & $84.32 \pm 0.06$ & $77.63 \pm 1.2$ \\
\hline
\end{tabular}

Values are expressed as mean $\pm \mathrm{SD}, \mathrm{n}=3$ sets in each group. Mean values followed in a column are significantly different $(\mathrm{p}<0.05)$. TPC: Total phenolic content, TFC: Total flavonoid content, TAC: Total alkaloid contents, SD: Standard deviation

Table 2: Reducing power assay and FRAP values of various plant extracts of bark of $P$. longifolia

\begin{tabular}{lll}
\hline Extract & $\begin{array}{l}\mathbf{E C}_{\mathbf{5 0}} \text { values for } \\
\text { reducing power } \\
\text { assay }(\boldsymbol{\mu g} / \mathbf{m l})\end{array}$ & $\begin{array}{l}\text { FRAP values for the } \\
\text { extract }(\boldsymbol{\mu g} / \mathbf{m l} \text { of ascorbic } \\
\text { acid equivalent) }\end{array}$ \\
\hline Hexane & $1100.09 \pm 0.03$ & $488.23 \pm 0.01$ \\
Ethyl acetate & $982.91 \pm 0.01$ & $550.67 \pm 0.07$ \\
Acetone & $530.66 \pm 0.06$ & $967.12 \pm 0.02$ \\
Methanol & $292.31 \pm 0.06$ & $830.34 \pm 0.05$ \\
Ascorbic acid & $910.37 \pm 0.01$ &
\end{tabular}

Values were performed in triplicates and represented as mean \pm SD. Mean values followed in a column are significantly different $(\mathrm{p}<0.05)$. FRAP: Ferric reducing antioxidant power, $\mathrm{EC}_{50}$ : Effective concentration 50, SD: Standard deviation

IC $_{50}$ of the acetone extract of $P$. longifolia $(10.78 \pm 0.01 \mu \mathrm{g} / \mathrm{ml})$ was found to be lowest than all other sample extract. However with the addition of a larger amount of bark extract of the plant to the DPPH assay mixture, the degree of inhibition decreased, indicating a prooxidant effect.

\section{Reducing power assay and FRAP assay}

As shown in Fig. 3, various extracts of $P$. longifolia exhibited a dosedependent increase in the ferric ion reducing potential. The lowest effective concentration $\left(\mathrm{EC}_{50}\right)$ was recorded in the acetone extract of P. longifolia bark with $292.31 \pm 0.06 \mu \mathrm{g} / \mathrm{ml}$, respectively, which was much lower than the $\mathrm{EC}_{50}$ of the standard, ascorbic acid $(910.37 \mu \mathrm{g} / \mathrm{ml})$. A detailed $\mathrm{EC}_{50}$ of various extracts and FRAP value of the plant is depicted in Table 2. The FRAP values ranged from 324.55 to $967.12 \mu \mathrm{g} / \mathrm{ml}$ AAE for various fractions of the plants and are shown in Table 2.

\section{Hydrogen peroxide scavenging activity}

As shown in Fig. 2, P. longifolia also demonstrated hydrogen peroxide decomposition activity in a concentration dependent manner with lowest $\mathrm{IC}_{50}$ exhibited by acetone extract of $P$. longifolia $\left(\mathrm{IC}_{50}=181.78 \mu \mathrm{g} / \mathrm{ml}\right)$ which was much lower than standard ascorbic acid, $\mathrm{IC}_{50}=228.97 \mu \mathrm{g} / \mathrm{ml}$.

\section{Metal chelating activity and TBA assay}

As observed in DPPH and hydroxyl radical scavenging assays, the percentage of metal chelating activity was determined to be sample concentration dependent and it was increasing with the increase in the concentration of extract from 50 to $300 \mu \mathrm{g} / \mathrm{ml}$. The percentage of inhibition of the metal chelation was varying from $35.77-37.53 \%$ (in $50 \mu \mathrm{g} / \mathrm{ml}$ of extract) to $80.19-87.41 \%$ (in $300 \mu \mathrm{g} / \mathrm{ml}$ extract). The $\mathrm{IC}_{50}$ value of the $P$. longifolia, the acetone extract showed highest $\mathrm{IC}_{50}$ with $92.11 \mu \mathrm{g} / \mathrm{ml}$. The percentage of inhibition of free radicals by various concentrations of acetone samples was more or less to that of the respective concentration of standard drug, ascorbic acid (Fig. 2).

Result of TBA assay depicted in Fig. 2 demonstrated the radical scavenging activity of various extracts of the plants where the $\mathrm{IC}_{50}$ values of acetone extract of P. longifolia $(24.88 \mu \mathrm{g} / \mathrm{ml})$ where significantly more than ascorbic acid $\left(\mathrm{IC}_{50}=35.77 \mu \mathrm{g} / \mathrm{ml}\right.$, taken as standard.

IC $_{50}$

$\mathrm{IC}_{50}$ values of various bark extracts of $P$. longifolia and standard ascorbic acid, butylated hydroxytolune, quercetin for DPPH, $\mathrm{H}_{2} \mathrm{O}_{2}$ radical

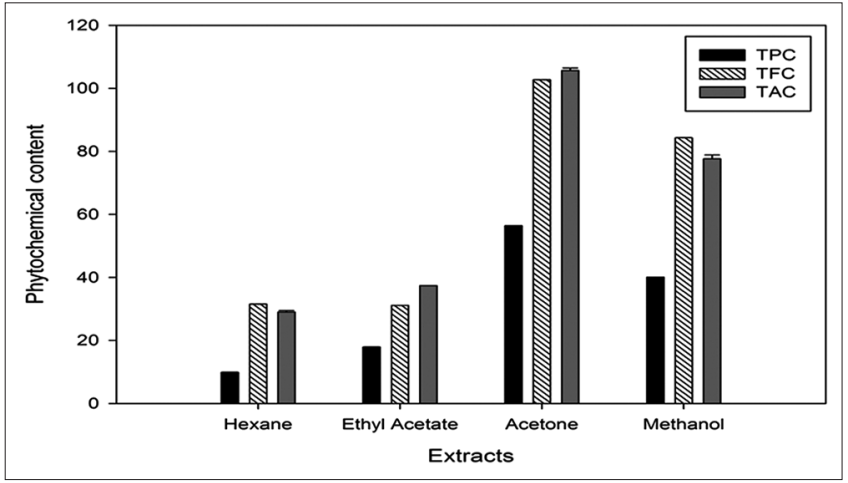

Fig. 1: Total phenol content, total flavonoid content and total alkaloid content estimated of various extract of Pajanelia longifolia

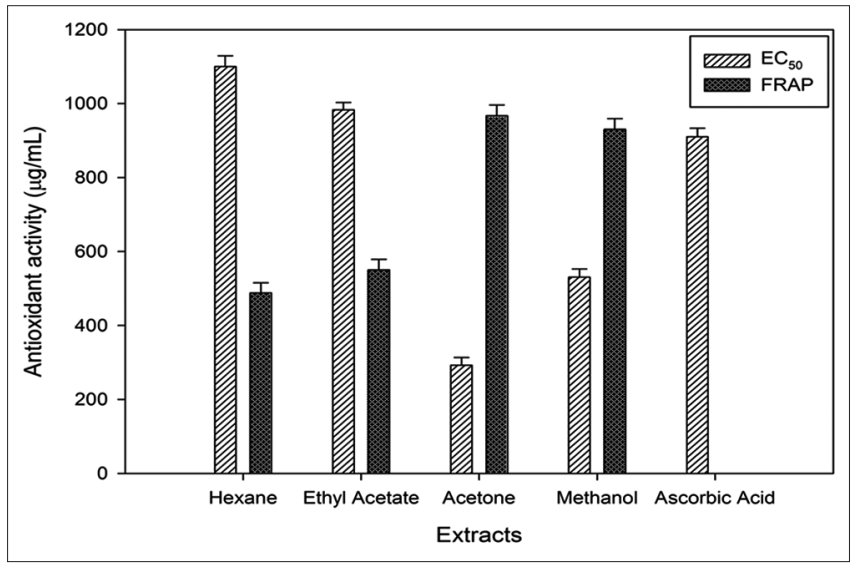

Fig. 2: 1,1-diphenyl-2-picrylhydrazyl radical scavenging activity, $\mathrm{H}_{2} \mathrm{O}_{2}$, chelating activity and thiobarbituric acid activity of the various bark extracts of Pajanelia longifolia in comparison with ascorbic acid

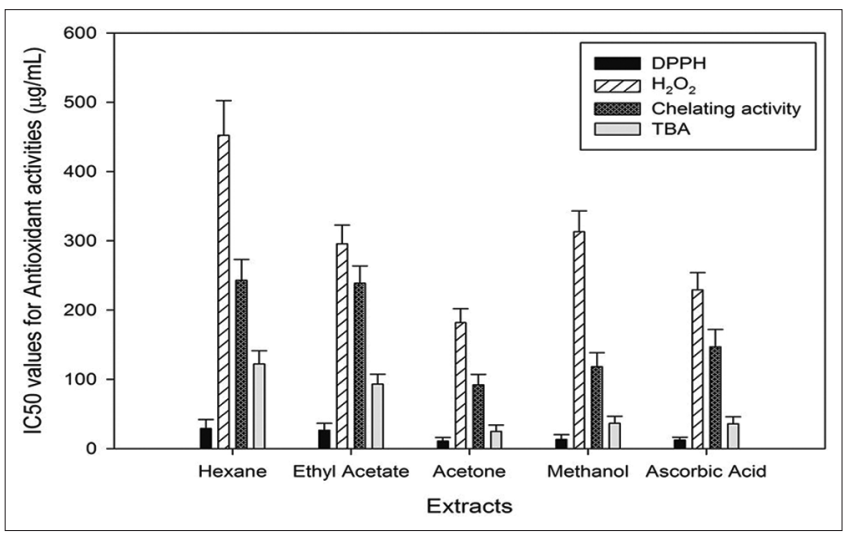

Fig. 3: Comparison of effective concentration 50 and ferric reducing antioxidant power values of various fractions of bark parts of Pajanelia longifolia 
Table 3: DPPH ${ }^{\circ} \mathrm{H}_{2} \mathrm{O}_{2}$ radical scavenging activity, ferrous chelating activity, TBA assay of various plant extracts of bark of P. longifolia

\begin{tabular}{|c|c|c|c|c|}
\hline \multicolumn{5}{|c|}{$\mathrm{IC}_{50}$ values for antioxidant activity $(\mu \mathrm{g} / \mathrm{ml})$} \\
\hline Extract & DPPH & $\mathbf{H}_{2} \mathbf{O}_{2}$ & $\begin{array}{l}\text { Chelating } \\
\text { activity }\end{array}$ & TBA \\
\hline $\mathrm{He}$ & .03 & 5 & $242.97 \pm 0.04$ & 2 \\
\hline Ethyl acetate & $26.54 \pm 0.02$ & $295.66 \pm 0.00$ & $238.78 \pm 0.03$ & $93.21 \pm 0.01$ \\
\hline Acetone & $10.78 \pm 0.01$ & $181.78 \pm 0.09$ & $92.11 \pm 0.02$ & $24.88 \pm 0.04$ \\
\hline Methanol & $13.08 \pm 0.03$ & $312.98 \pm 0.01$ & $118.22 \pm 0.04$ & $36.45 \pm 0.03$ \\
\hline $\begin{array}{l}\text { Ascorbic } \\
\text { acid }\end{array}$ & $12.25 \pm 0.01$ & $228.97 \pm 0.01$ & $146.89 \pm 0.03$ & $35.77 \pm 0.07$ \\
\hline
\end{tabular}

DPPH: 1,1-diphenyl-2-picrylhydrazyl, TBA: Thiobarbituric acid, $\mathrm{IC}_{50}$ : Inhibitory concentration 50

scavenging activity, ferrous chelating activity, TBA are depicted in Table 3 .

\section{DISCUSSION}

In the initial phytochemical screening, high phenol and flavonoid content were recorded in acetone extract of P. longifolia, while hexane extract in the instances; the said phytochemical group appeared as low. To progress further with the aim to understand the related activity of the said extracts noticeable free radical scavenging activity was observed in DPPH assay. Maximum radical scavenging activity was exhibited by the acetone extract of $P$. longifolia implying that phenol and flavonoid content is positively correlated to the antioxidant activity of a plant [16-18]. Considering evidence from literature [19-22], the involvement of phenols and flavonoid in antioxidant activity can be established. Thus, the present findings in this context, summarizes with the same concept without any deviation.

Similar antioxidant efficacy was observed for the extracts using other chemical assays, viz.; reducing power assay, $\mathrm{H}_{2} \mathrm{O}_{2}$ scavenging activity, FRAP assay, metal chelating activity, and TBA assay. This means, in all the cases acetone extract of $P$. longifolia exhibited the higher antioxidant activity in comparison to the positive control. This finding invariably authenticates the antioxidant potential of $P$. longifolia in general and acetone extracts, respectively, in particular

P. longifolia showed highest alkaloid content in acetone extract. Interestingly, both the above extracts also showed highest antioxidant activity in comparison to the other extracts. Although the general concept is that among all chemical groups, flavonoids and phenols are the major groups responsible for antioxidant-oxidant activity; our study proposes a direct correlation between alkaloid content and antioxidant activity of plants. While working with Turkish tea polyphenols and alkaloid Erol et al. [23] proposed that alkaloid content is linked with antioxidant activity. Racková et al. [24] suggested that probably high lipophilicity of the alkaloids is responsible for antiradical reactivity. The study suggests that acetone extract from $P$. longifolia bark are a rich source of antioxidants that may be developed as a safer, non-toxic and functional ingredient in nutraceutical or pharmaceutical or therapeutic products. Further, their mode of action is still to be understood.

\section{ACKNOWLEDGMENTS}

The authors are grateful to DBT (Government of India) Sponsored Institutional Biotech. Hub and Bioinformatics Infrastructure Facility of Assam University and Delcon's e-Journal Access Facility.

\section{REFERENCES}

1. Zainab A, Bhat RP, Acharya S, Yende A, Prajna PS, Padyana S. Studies on antioxidant and antimicrobial activities of Pajanelia longifolia
(Willd.) Schumann. J Res Obes 2013;1-12. Available from: http://www. ibimapublishing.com/articles/OBES/2013/756484/756484.pdf.

2. Chin YW, Balunas MJ, Chai HB, Kinghorn AD. Drug discovery from natural sources. AAPS J 2006;8(2):E239-53.

3. Choudhury S, Choudhury MD, Sharma GD, Paul SB. Antibacterial activity of crude leaf extracts of Pajanelia longifolia (Wild.) K Schuman. Assam Univ J Sci Technol 2010;5:53-7. Available from: http://www.inflibnet.ac.in/ojs/index.php/AUJSAT/article/view/61/58.

4. Sharma P, Mazumder S, Choudhury S. Preliminary phytochemical screening and anti-bacterial activity of the leaves of Pajanelia longifolia (Wild.) K Schuman and Crataeva magna (Lour.) DC. Indo Am J Pharm Res 2013;3:8165-8. Available from: http://www.ejmanager.com/ mnstemps/36/36-1393662065.pdf.

5. Datta S, Choudhury S, Choudhury MD. Hepatoprotective activity of bark extracts of Pajanelia longifolia (Willd.) K. Schuman against CCl induced hepatic damage in mice. Drug Invent Today 2012;4:537-9. Available from: http://www.jprsolutions.info/newfiles/journal-file55efb235ce8b09.72866367.pdf.

6. Kameswaramma A, Seshadri TR. Proc Indian Acad Sci Math Sci 1947;25:43. Available from: http://www.link.springer.com/ article/10.1007/BF03172544.

7. Slinkard K, Singleton VL. Total phenol analyses: Automation and comparison with manual methods. Am J Enol Vitic 1977;28:49-55. Available from: http://www.ajevonline.org/content/28/1/49.short.

8. Arvouet-Grand A, Vennat B, Pourrat A, Legret P. Standardization of propolis extract and identification of principal constituents. J Pharm Belg 1994;49:462-8.

9. Ajanal M, Gundkalle MB, Nayak SU. Estimation of total alkaloid in Chitrakadivati by UV-Spectrophotometer. Anc Sci Life 2012;31(4):198-201.

10. Kumarasamy Y, Byres M, Cox PJ, Jaspars M, Nahar L, Sarker SD. Screening seeds of some Scottish plants for free radical scavenging activity. Phytother Res 2007;21(7):615-21.

11. Oyaizu M. Antioxidative activities of browning reaction prepared from glucosamine. Jpn J Nutr 1986;44:307-15. Available from: https://www. jstage.jst.go.jp/article/eiyogakuzashi1941/44/6/44 6 307/ article.

12. Jayaprakasha GK, Jaganmohan Rao L, Sakariah KK. Antioxidant activities of flavidin in different in vitro model systems. Bioorg Med Chem 2004;12(9):5141-6

13. Benzie IF, Strain JJ. The ferric reducing ability of plasma (FRAP) as a measure of "antioxidant power": The FRAP assay. Anal Biochem 1996;239:70-6. Available from: http://www.sciencedirect.com/science/ article/pii/S0003269796902924.

14. Yan LY, Teng LT, Jhi TJ. Antioxidant properties of guava fruits: Comparison with some local fruits. Sunway Acad J 2006;3:9-20.

15. Kikuzaki H, Nakatani N. Antioxidant effects of some ginger constituents. J Food Sci 1993;58:1407-10. Available from: http://www. onlinelibrary.wiley.com/doi/10.1111/j.1365-h21.1993.tb06194.x/pdf.

16. Gheldof N, Engeseth NJ. Antioxidant capacity of honeys from various floral sources based on the determination of oxygen radical absorbance capacity and inhibition of in vitro lipoprotein oxidation in human serum samples. J Agric Food Chem 2002;50:3050-55.

17. Holasova M, Fiedlerova V, Smrcinova H, Orsak M, Lachman J, Vavreinova S. Buckwheat-the source of antioxidant activity in functional foods. Food Res Int 2002;35:207-211. Available from: http:// www.sciencedirect.com/science/article/pii/S0963996901001855.

18. Aljadi AM, Kamaruddin MY. Evaluation of the phenolic contents and antioxidant capacities of two Malaysian floral honeys. Food Chem 2004;85:513-8. Available from: http://www.sciencedirect.com/science/ article/pii/S0308814602005964.

19. Song FL, Gan RY, Zhang Y, Xiao Q, Kuang L, Li HB. Total phenolic contents and antioxidant capacities of selected Chinese medicinal plants. Int J Mol Sci 2010;11(6):2362-72.

20. Kumar VS, Kumar GS, Sivaramakrishnan S, Sujatha K, Razia M. Evaluation of phytoconstituents, in vitro antioxidant and antimicrobial activities of edible white button mushroom Agaricus bisporus. Asian J Pharm Clin Res 2016;8:67-71. Available from: http:// innovareacademics.in/journals/index.php/ijpps/article/view/8616.

21. Meziti A, Bouriche H, Hiche M, Kada S, Senator A, Dimertas I. Antioxidant and anti-inflammatory activities of Rubus fruticosus and Zizyphus vulgaris methanol extracts. Int J Pharm Pharm Sci 2017;9:6976. Available from: http://www.innovareacademics.in/journals/index. php/ijpps/article/view/14374

22. Parameshwar P, Reddy YN. Protective role, in vitro free radical scavenging activities of Alangium salvifolium (linn) against $\mathrm{CCl}_{4}$ induced hepatic damage in rats. Int J Pharm Pharm Sci 2015;7:447-52. 
Available from: http://www.innovareacademics.in/journals/index.php/ ijpps/article/view/4480.

23. Erol N, Sarı F, Velioglu Y. Polyphenols, alkaloids and antioxidant activity of different grades Turkish black tea. GIDA 2010;35:161-8. Available from: https:/www.researchgate.net/publication/255649072_
Polyphenols alkaloids and antioxidant activity of different grades turkish_black tea.

24. Racková L, Májeková M, Kost’álová D, Stefek M. Antiradical and antioxidant activities of alkaloids isolated from Mahonia aquifolium. Structural aspects. Bioorg Med Chem 2004;12(17):4709-15. 